\title{
Effects of supplemental irrigation based on soil water content on water consumption, dry matter and yield of wheat
}

\author{
Yongli Zhang ${ }^{1}$, Zhenwen Yu${ }^{1 *}$, Yu Shi ${ }^{1}$, Shubo Gu ${ }^{1}$, and Yanyan Zhang ${ }^{1,2}$ \\ 'Shandong Agricultural University, Agronomy College, Key Laboratory of Crop Ecophysiology and Cultivation, Ministry of \\ Agriculture, Taian 271018, P.R. China. "Corresponding author (sdauwheat@sina.cn). \\ ${ }^{2}$ Tai'an Academy of Agriculture Sciences, Taian 271000, P.R. China.
}

Received: 20 August 2018; Accepted: 6 December 2018; doi:10.4067/S0718-58392019000200190

\begin{abstract}
Water-saving cultivation in wheat (Triticum aestivum L.) is an important technique for achieving high yield and high water use eficiency (WUE) in the North China Plain (NCP) where water resources are in shortage. In order to determine the effects of supplemental irrigation based on soil water content on crop evapotranspiration (ET), DM, grain yield and WUE in wheat, treatments were designed to vary the relative soil water content at jointing and anthesis stages: $\mathrm{I}_{70}$ $(70 \%, 70 \%)$ and $\mathrm{I}_{75}(75 \%, 75 \%)$ with rain-fed $\left(\mathrm{I}_{0}\right)$ and traditional irrigation $\left(\mathrm{I}_{\mathrm{ck}}\right)$ as contrasts. The results indicated that the irrigation amount of $\mathrm{I}_{70}$ and $\mathrm{I}_{75}$ were significantly lower than that of $\mathrm{I}_{\mathrm{ck}}$ by 45.1 to $132.4 \mathrm{~mm}$, but soil water depletion increased by 23.5 to $35.4 \mathrm{~mm}$. Although the total ET throughout the growing season (ETt) of $\mathrm{I}_{75}$ was less than that of $\mathrm{I}_{\mathrm{ck}}$, the ratio to ETt from anthesis to maturity increased significantly. The DM partitioning ratio was decreased in vegetable organs, but increased in grain for $\mathrm{I}_{75}$ compared with $\mathrm{I}_{c k}$. The grain yield for $\mathrm{I}_{75}$ was significantly higher than that of $\mathrm{I}_{0}$ and $I_{70}$, whereas nonsignificant difference was observed between $I_{75}$ and $I_{c k}$, and the WUE and irrigation water use efficiency of $\mathrm{I}_{75}$ were higher than those of $\mathrm{I}_{\text {ck }}$ by $11.0 \%$ and $87.4 \%$ in $2008-2009$ and 3.5\% and 34.0\% in 2009-2010. Thus, $\mathrm{I}_{75}$ can be developed as an optimal water-saving irrigation regimes in the NCP.
\end{abstract}

Key words: Dry matter accumulation and partitioning, grain yield, Triticum aestivum, water consumption characterization, water use efficiency.

\section{INTRODUCTION}

Winter wheat (Triticum aestivum L.) is the main crop in the North China Plain (NCP) and supplies more than 60\% of wheat throughout China (Shi et al., 2013). During the winter wheat growing season, crop evapotranspiration (ET) is approximately 400 to $500 \mathrm{~mm}$, but the mean precipitation does not exceed $200 \mathrm{~mm}$ (Li et al., 2012a). Therefore, water is the main limiting factor for winter wheat production, and irrigation is essential to maintaining high winter wheat yields (Wang et al., 2015; Xu et al., 2018) in this region. In most parts of the NCP, more than 70\% of irrigation water resources are used for winter wheat, and most of these water resources come from groundwater. Although flood irrigation is traditionally performed for three to five times or six to seven times during the winter wheat growing season in the NCP, water use efficiency (WUE) is low (Zhang et al., 2017). The extensive exploitation of the groundwater resources in this region for irrigation, causes numerous other environmental problems (Hayriye et al., 2015). Thus, optimum irrigation strategies are urgently needed to prevent further groundwater exploitation, to produce wheat sustainably, and to improve WUE.

Many optimized irrigation scheduling strategies have been thoroughly studied and widely applied to improve wheat yield and increase WUE (Abdelkhalek et al., 2015; Fang et al., 2018). Li et al. (2009) reported that irrigation at jointing 
and heading stages with $60 \mathrm{~mm}$ water improves grain yield by $127.54 \mathrm{~g} \mathrm{~m}^{-2}$ compared with irrigation performed only at heading stage with $120 \mathrm{~mm}$ water. Lv et al. (2011) recommended that a single application of irrigation 60 to $70 \mathrm{~mm}$ at jointing produced higher yields and a higher WUE than traditional irrigation practices. Reducing the frequency of irrigation and thereby reducing the total irrigation water input can potentially increase WUE (Zhang et al., 2018). In these studies, fixed irrigation amounts, such as $60,70,120 \mathrm{~mm}$, and others, were applied. In other trials, irrigation amounts were determined based on ET (Li et al., 2012b) or estimated using mathematical models (Peake et al., 2016).

Available soil water and precipitation are important water sources for wheat growth. However, irrigation is applied at critical stages of wheat development, often ignoring precipitation and the availability of soil water. In the NCP, approximately $70 \%$ of annual precipitation occurs before winter wheat sowing, usually replenishing some of the soil water; furthermore, the water stored in the soil profile is important in supplying water to winter wheat, and soil water depletion could contribute $40 \%-60 \%$ of the seasonal evapotranspiration under limited water supply (Fang et al., 2018). A positive relationship between available water at planting and wheat grain yield was reported (Schillinger et al., 2008). However, few studies to date have focused on soil water content (SWC) before defining the irrigation quota, thereby wasting irrigation water. Thus, irrigation practices based on the consideration of precipitation and SWC should be developed to save greater amounts of water during wheat production.

The most important period for the three primary yield components occurs after jointing in winter wheat (Cai et al., 2014). The water requirement of winter wheat reaches its peak in April and May in the NCP (Zhang et al., 2013). Studies have shown that water deficits applied in stem elongation and heading stages significantly decrease wheat yields (Tari, 2016), and that the drought following anthesis can negatively affect photosynthetic characteristics as well as significantly advance senescence in flag leaves (Wu et al., 2014). Meanwhile, moderate water deficits during jointing resulted in similar grain yields compared with the control (Cui et al., 2015). However, knowledge of the water consumption characterization (such as ET of individual growth stages and their ratios to total ET) corresponding to supplemental irrigation based on soil water content is relatively limited.

In this study, a new irrigation method was adopted, and we monitored the SWC in the 0 to $140 \mathrm{~cm}$ soil layer before irrigation. Then the irrigation amounts were estimated based on SWC and implemented to design relative SWC (RSWC) at critical growth stages of wheat. The following were our objectives: (1) to investigate the utilization characteristics of irrigation, soil water depletion, and precipitation, and the ET of individual growth stages and their ratios to total crop ET (ETt); (2) to evaluate DM accumulation at different growing stages of wheat and partitioning in grain and vegetable organs at maturity; (3) to clarify the effects of supplement irrigation based on soil water content on grain yield and water use efficiency under field conditions; and (4) to explore the optimal water-saving irrigation regimes in the NCP.

\section{MATERIALS AND METHODS}

\section{Study site and experiment design}

Field experiments were conducted for 2008-2009 and 2009-2010 winter wheat growing seasons at the Agronomy Experimental Station of Shandong Agricultural University (36 $\left.10^{\prime} \mathrm{N}, 117^{\circ} 9^{\prime} \mathrm{E}\right)$ in northern China. The typical growing season for winter wheat is from early October until the middle of June. The average annual precipitation of $675 \mathrm{~mm}$. Because of the effect of typical continental monsoon climate, the temporal distribution of annual rainfall in the North China Plain (NCP) is extremely variable, with more than $70 \%$ concentrated in the maize growing season (July to September), but only approximately $30 \%$ of which occurs during the winter wheat growing season.

Precipitation data were collected during the winter wheat growing season from weather station about $200 \mathrm{~m}$ away from the trial plots (Table 1).

The loamy soil at the experimental site has been intensively cultivated for many years. The $0-20 \mathrm{~cm}$ soil layer contained $1.42 \%$ organic matter, $0.15 \%$ total $\mathrm{N}, 106.1 \mathrm{mg} \mathrm{kg}^{-1}$ available $\mathrm{N}, 33.2 \mathrm{mg} \mathrm{kg}^{-1}$ available $\mathrm{P}$, and $113.8 \mathrm{mg} \mathrm{kg}^{-1}$ available K. The soil bulk density, mass soil water content (MSWC) and field water capacity in 0-140 cm soil layer before sowing are shown in Table 2.

The test material was high-yield winter wheat 'Jimai 22'. In both growing seasons, two identical supplemental irrigation treatments based on soil water content (SWC) were designed wherein the controlled average target relative SWC (RSWC) in the 0 to $140 \mathrm{~cm}$ soil layer at jointing (Z31, first node is detectable; 2009-4-8 and 2010-4-4) and anthesis (Z61, beginning of anthesis; 2009-5-4, 2010-4-30) stages (Zadoks et al., 1974) reached 70\% ( $\left.\mathrm{I}_{70}\right)$ and 75\% $\left(\mathrm{I}_{75}\right)$, respectively (Table 3). 
Table 1. Monthly rainfall during winter wheat growing seasons ( $\mathrm{mm})$.

\begin{tabular}{lrrrrrrrrrr}
\hline Growing season & \multicolumn{1}{c}{ Oct } & Nov & Dec & Jan & Feb & Mar & Apr & May & Jun & Total \\
\hline $2008-2009$ & 9.9 & 4.9 & 0.3 & 0.0 & 12.1 & 25.7 & 46.1 & 42.8 & 1.0 & 142.8 \\
$2009-2010$ & 12.9 & 21.3 & 6.2 & 3.2 & 18.9 & 14.8 & 20.5 & 42.0 & 9.3 & 149.1
\end{tabular}

Table 2. Soil bulk density, mass soil water content and field water capacity of the tested soil.

\begin{tabular}{|c|c|c|c|c|c|c|}
\hline \multirow[b]{2}{*}{$\begin{array}{c}\text { Soil } \\
\text { layer }\end{array}$} & \multicolumn{3}{|c|}{ 2008-2009 growing season } & \multicolumn{3}{|c|}{ 2009-2010 growing season } \\
\hline & $\begin{array}{c}\text { Soil bulk } \\
\text { density }\end{array}$ & $\begin{array}{c}\text { Mass soil } \\
\text { water content }\end{array}$ & $\begin{array}{c}\text { Field water } \\
\text { capacity }\end{array}$ & $\begin{array}{c}\text { Soil bulk } \\
\text { density }\end{array}$ & $\begin{array}{c}\text { Mass soil } \\
\text { water content }\end{array}$ & $\begin{array}{l}\text { Field water } \\
\text { capacity }\end{array}$ \\
\hline $\mathrm{cm}$ & $\mathrm{g} \mathrm{cm}^{-3}$ & $-\mathrm{g}$ & & $\mathrm{g} \mathrm{cm}^{-3}$ & $-\mathrm{g} \mathrm{g}$ & \\
\hline $0-20$ & 1.45 & 0.191 & 0.277 & 1.46 & 0.16 & 0.285 \\
\hline $20-40$ & 1.52 & 0.173 & 0.253 & 1.51 & 0.18 & 0.253 \\
\hline $40-60$ & 1.53 & 0.189 & 0.250 & 1.52 & 0.19 & 0.248 \\
\hline $60-80$ & 1.55 & 0.193 & 0.254 & 1.55 & 0.20 & 0.249 \\
\hline $80-100$ & 1.57 & 0.206 & 0.248 & 1.57 & 0.20 & 0.244 \\
\hline $100-120$ & 1.56 & 0.232 & 0.249 & 1.56 & 0.23 & 0.248 \\
\hline $120-140$ & 1.57 & 0.246 & 0.242 & 1.57 & 0.28 & 0.245 \\
\hline
\end{tabular}

Table 3. Target relative soil water contents (RSWC) or irrigation amount at jointing and anthesis stages.

\begin{tabular}{ccc}
\hline & \multicolumn{2}{c}{ Average target RSWC in 0-140 cm soil layer or } \\
\cline { 2 - 3 } irrigation amount & \\
\cline { 2 - 3 } Treatments & Jointing stage & Anthesis stage \\
\hline $\mathrm{I}_{70}$ & $70 \%$ & $70 \%$ \\
$\mathrm{I}_{75}$ & $75 \%$ & $75 \%$ \\
$\mathrm{I}_{0}$ & $0 \mathrm{~mm}$ & $0 \mathrm{~mm}$ \\
$\mathrm{I}_{\mathrm{ck}}$ & $60 \mathrm{~mm}$ & $60 \mathrm{~mm}$ \\
\hline
\end{tabular}

$70 \%\left(\mathrm{I}_{70}\right)$ and $75 \%\left(\mathrm{I}_{75}\right)$ were the average RSWC of the $0-140 \mathrm{~cm}$ soil layer after supplemental irrigation.

A rain-fed treatment $\left(I_{0}\right)$ and a conventional irrigation treatment $\left(I_{c k}\right)$, which were supplied with $60 \mathrm{~mm}$ water at the prewinter, jointing, and anthesis stages, were established as controls.

Before irrigation at the jointing and anthesis stages, SWC of 0-140 $\mathrm{cm}$ soil layer was tested with three times replication of each sample. The average $\mathrm{SWC}$ of $\mathrm{I}_{0}, \mathrm{I}_{70}, \mathrm{I}_{75}$ and $\mathrm{I}_{\mathrm{ck}}$ in $0-140 \mathrm{~cm}$ soil layer were $0.157,0.157,0.159$ and $0.172 \mathrm{~g} \mathrm{~g}^{-1}$ at jointing stage, and were $0.153,0.176,0.175$ and $0.174 \mathrm{~g} \mathrm{~g}^{-1}$ at anthesis stage in 2008-2009. In 2009-2010, the values were $0.167,0.168,0.168$ and $0.182 \mathrm{~g} \mathrm{~g}^{-1}$ at jointing stage, and $0.143,0.143,0.149$ and $0.161 \mathrm{~g} \mathrm{~g}^{-1}$ at anthesis stage. The amount of supplemental irrigation was calculated using Equation [1] (Man et al., 2016):

$$
I=10 v h\left(\beta_{i}-\beta_{j}\right) \text {, }
$$

where $I$ is the amount of supplemental irrigation $(\mathrm{mm}), v$ is soil bulk density of the designed moisture soil layer $\left(\mathrm{g} \mathrm{cm}^{-3}\right)$, $h$ is the soil layer depth $(\mathrm{cm}), \beta_{i}$ is the designed target mass water content (field water capacity $\times$ target average RSWC), and $\beta_{j}$ is soil mass water content before irrigation.

A supplemental irrigation event occurred the next day after the relative SWC of 0-140 cm soil layer was tested at the jointing and anthesis. Supplemental irrigation water was supplied from a pump outlet to the plots using soft plastic pipes, and the amount of irrigation was measured using flow meters fitted to the plastic pipes for each plot.

On the third day after SI, soil samples of 0-200 cm layer were collected to calculate the RSWC, and each sample was replicated three times.

Each experiment plot was $2 \times 10 \mathrm{~m}$ and was designed in a randomized block with three replicates. A $1 \mathrm{~m}$-wide buffer zone around each plot was sown with same wheat cultivar. The winter wheat seeds were sown at a rate of 180 grains m$^{-2}$ on 8 October both years, and were harvested on 8 June in 2009 and on 14 June in 2010. Before sowing, urea (46.4\% N), diammonium phosphate $\left(46 \% \mathrm{P}_{2} \mathrm{O}_{5}\right.$ and $\left.18 \% \mathrm{~N}\right)$, and potassium sulfate $\left(52 \% \mathrm{~K}_{2} \mathrm{O}\right)$ were applied to provide $105 \mathrm{~kg} \mathrm{~N} \mathrm{ha}^{-1}$, $112.5 \mathrm{~kg} \mathrm{P}_{2} \mathrm{O}_{5} \mathrm{ha}^{-1}$, and $112.5 \mathrm{~kg} \mathrm{~K}_{2} \mathrm{O} \mathrm{ha}{ }^{-1}$ as the basal fertilizer, and the urea was added to provide $135 \mathrm{~kg} \mathrm{~N} \mathrm{ha}^{-1}$ at the jointing stage. 


\section{Measurements}

The field water capacity was determined using the single-ring method. The MSWC and RSWC were measured at $20 \mathrm{~cm}$ increments using the oven-drying method, and were calculated by Equations [2] and [3]:

MSWC $(\%)=($ fresh weight of soil sample - dry weight of soil sample $) /$ dry weight of soil sample $\times 100$

RSWC $(\%)=$ MSWC/field water capacity $\times 100$

The total evapotranspiration (ETt) during the whole growing season and individual growth stages of wheat were calculated using the soil water balance Equation [4] (Xu et al., 2017):

$$
E T=P+I+\Delta W-R-D
$$

where $P(\mathrm{~mm})$ is precipitation, $I(\mathrm{~mm})$ is the irrigation amount, $\Delta W(\mathrm{~mm})$ is the soil water storage at sowing minus the soil water storage at harvesting for the $0-200 \mathrm{~cm}$ soil profile, $R(\mathrm{~mm})$ is the surface runoff, $D$ is the water lost through deep percolation. When the groundwater table is lower than $2.5 \mathrm{~m}$ below the soil surface, as it is at the experimental site, the capillary rising of groundwater is negligible (Ali et al., 2007). Runoff and the drainage can also be ignored in the North China Plain, including this experimental site (Lv et al., 2011). As a result, Equation [4] becomes Equation [5]:

$$
E T=I+P+\Delta W
$$

The $\Delta W$ was calculated using Equation [6]:

$$
\Delta W=0.1 \beta v h
$$

where $\Delta W$ is the soil water storage amount in different depths $(\mathrm{mm}), \beta$ is the soil mass water content $(\%), v$ is the soil bulk density $\left(\mathrm{g} \mathrm{cm}^{-3}\right), h$ is the soil layer depth $(\mathrm{cm})$, and 0.1 is the conversion factor.

Thirty culms randomly chosen were collected at jointing, anthesis and maturity stages, and were separated into grain and vegetable organ at maturity. All of the plant samples were oven dried at $70{ }^{\circ} \mathrm{C}$ until a constant weight was achieved to determine above ground biomass.

The wheat plants were harvested for grain yield on 8 June in 2009 and 14 June in 2010. After air-drying, dry weight of the grain was measured.

The water use efficiency (WUE) and irrigation water use efficiency (IWUE) were estimated by Equations [7] and [8]:

$$
\begin{gathered}
W U E=Y / E T t \\
I W U E=\Delta Y / I
\end{gathered}
$$

where WUE is the water use efficiency $\left(\mathrm{kg} \mathrm{ha}^{-1} \mathrm{~mm}^{-1}\right), Y$ is the grain yield $\left(\mathrm{kg} \mathrm{ha}^{-1}\right)$, ETt is total evapotranspiration from field emergence to maturity stage of winter wheat. IWUE is the irrigation water use efficiency $\left(\mathrm{kg} \mathrm{ha}^{-1} \mathrm{~mm}^{-1}\right), \Delta Y$ is the grain yield increment after irrigation $\left(\mathrm{kg} \mathrm{ha}^{-1}\right)$, and $I$ is the actual amount of irrigation (mm) (Suat et al., 2016).

\section{Data analysis}

Data analysis was performed using SPSS 13.0 (IBM, Armonk, New York, USA). Multiple comparisons were conducted with least significant difference (LSD) for a probability level of $\mathrm{P}=0.05$. Correlation analysis was performed using linear or quadratic function models of the SigmaPlot 12.5 (Systat Software, San Jose, California, USA).

\section{RESULTS AND DISCUSSION}

\section{RSWC at jointing, anthesis, and maturity stages}

Soil water content which are affected by irrigation and rainfall or by climate change affects DM accumulation and grain yield (Liu et al., 2016; Stolpe and Undurraga, 2016). In our study, the irrigation amounts in $\mathrm{I}_{70}$ and $\mathrm{I}_{75}$ were 44.6 and 66.3 $\mathrm{mm}$ at the jointing stage and 3 and $33.5 \mathrm{~mm}$ at the anthesis stage in 2008-2009, and were 20.5 and $47.6 \mathrm{~mm}$ at the jointing stage, 74.3 and $87.3 \mathrm{~mm}$ at the anthesis stage in 2009-2010, respectively. At jointing post-irrigation, the RSWC of 0-40 $\mathrm{cm}$ soil layer was ranked as $\mathrm{I}_{0}<\mathrm{I}_{70}<\mathrm{I}_{75}<\mathrm{I}_{\mathrm{ck}}$ in both growing seasons (Figure 1). Nonsignificant difference was observed in the RSWC of 60-200 cm soil layer among the treatments. At anthesis post-irrigation, the RSWC of 0-180 cm soil layer in $\mathrm{I}_{0}$ was significantly lower than in $\mathrm{I}_{70}, \mathrm{I}_{75}$ and $\mathrm{I}_{\mathrm{ck}}$ in both growing seasons. The RSWC of 0-120 cm soil layer in $\mathrm{I}_{75}$ was significantly greater than that of $I_{70}$ but lower than that of $I_{c k}$ in 2008-2009, while there was nonsignificant difference between $\mathrm{I}_{75}$ and $\mathrm{I}_{\mathrm{ck}}$ in 2009-2010. The different supplemental irrigation amount resulted in the difference of RSWC among treatments and interannual. At maturity, the RSWC of $120-160 \mathrm{~cm}$ soil layer was ranked as $\mathrm{I}_{0}<\mathrm{I}_{70}<\mathrm{I}_{75}<\mathrm{I}_{\mathrm{ck}}$, while there were nonsignificant difference in 0-120 and 180-200 cm soil layer in both growing seasons. 
Figure 1. Relative soil water content of different treatments at jointing and anthesis post-irrigation and maturity.
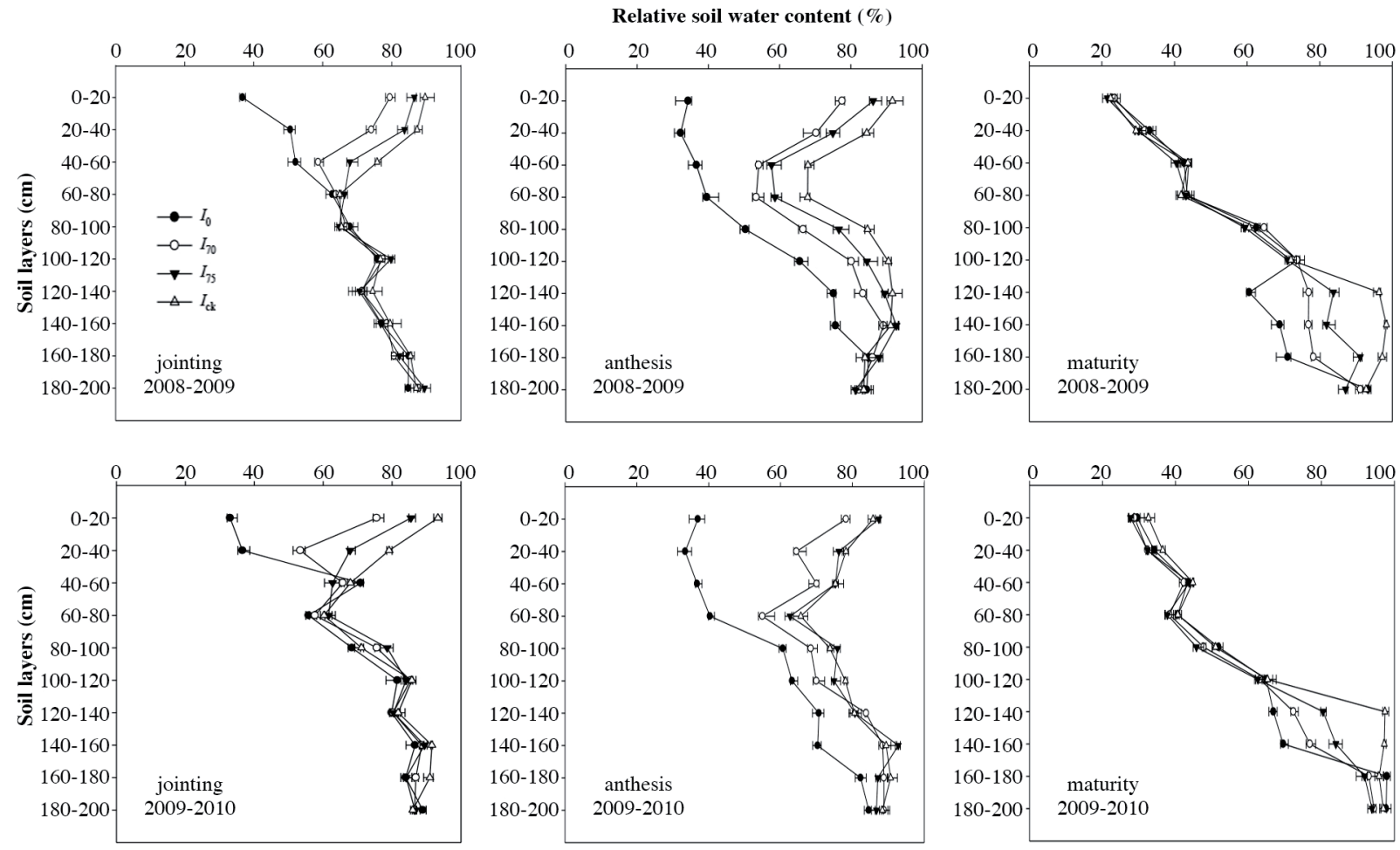

Irrigation, soil water depletion, precipitation, and their percentage to ETt

Under limited water supply, the available water for crops is related to the stored soil water, seasonal rainfall and irrigation amount, and their distribution. Table 4 shows that the irrigation water varied with target RSWC and across years. The irrigation amounts of $\mathrm{I}_{70}$ and $\mathrm{I}_{75}$ were 47.6 and $99.8 \mathrm{~mm}$ in 2008-2009 and were 94.8 and $134.9 \mathrm{~mm}$ in 2009-2010. These amounts were significantly lower than those of $\mathrm{I}_{\mathrm{ck}}$ by 132.4 and $80.2 \mathrm{~mm}$ in $2008-2009$ and by 85.2 and $45.1 \mathrm{~mm}$ in 2009-2010, respectively. The percentage of irrigation amount to ETt (PI) of $\mathrm{I}_{70}$ and $\mathrm{I}_{75}$ decreased by $67.1 \%$ and $38.7 \%$, respectively, in 2008-2009 and 40.6\% and 22.7\%, respectively, in 2009-2010 compared with that of $\mathrm{I}_{\mathrm{ck}}$. This results

Table 4. Irrigation, soil water depletion, precipitation and their percentage to total evapotranspiration (ETt).

\begin{tabular}{|c|c|c|c|c|c|c|c|}
\hline \multirow[b]{2}{*}{ Treatments } & \multirow[b]{2}{*}{ ETt } & \multicolumn{2}{|c|}{ Irrigation } & \multicolumn{2}{|c|}{ Soil water depletion } & \multicolumn{2}{|c|}{ Precipitation } \\
\hline & & Amount & PI & Amount & PS & Amount & PP \\
\hline & $\mathrm{mm}$ & $\mathrm{mm}$ & $\%$ & $\mathrm{~mm}$ & $\%$ & $\mathrm{~mm}$ & $\%$ \\
\hline \multicolumn{8}{|l|}{ 2008-2009 } \\
\hline $\mathrm{I}_{0}$ & $360.3 d$ & $0.0 \mathrm{~d}$ & $0.0 \mathrm{~d}$ & $217.5 \mathrm{a}$ & $60.4 \mathrm{a}$ & 142.8 & $39.6 \mathrm{a}$ \\
\hline $\mathrm{I}_{70}$ & $399.9 \mathrm{c}$ & $47.6 \mathrm{c}$ & $11.9 \mathrm{c}$ & $209.5 \mathrm{~b}$ & $52.4 \mathrm{~b}$ & 142.8 & $35.7 b$ \\
\hline $\mathrm{I}_{75}$ & $449.0 \mathrm{~b}$ & $99.8 \mathrm{~b}$ & $22.2 \mathrm{~b}$ & $206.4 \mathrm{~b}$ & $46.0 \mathrm{c}$ & 142.8 & $31.8 \mathrm{c}$ \\
\hline$I_{c k}$ & $496.9 \mathrm{a}$ & $180.0 \mathrm{a}$ & $36.2 \mathrm{a}$ & $174.1 \mathrm{c}$ & $35.0 \mathrm{~d}$ & 142.8 & $28.7 \mathrm{~d}$ \\
\hline ANOVA & $* *$ & $* *$ & $* *$ & * & $* *$ & & $* *$ \\
\hline \multicolumn{8}{|l|}{$2009-2010$} \\
\hline $\mathrm{I}_{0}$ & $441.3 \mathrm{c}$ & $0.0 \mathrm{~d}$ & $0.0 \mathrm{~d}$ & $292.2 \mathrm{a}$ & $66.2 \mathrm{a}$ & 149.1 & $33.8 \mathrm{a}$ \\
\hline $\mathrm{I}_{70}$ & $484.4 \mathrm{~b}$ & $94.8 \mathrm{c}$ & $19.6 \mathrm{c}$ & $240.5 b$ & $49.6 \mathrm{~b}$ & 149.1 & $30.8 b$ \\
\hline $\mathrm{I}_{75}$ & $528.2 \mathrm{a}$ & $134.9 \mathrm{~b}$ & $25.5 \mathrm{~b}$ & $244.2 \mathrm{~b}$ & $46.2 \mathrm{c}$ & 149.1 & $28.2 \mathrm{c}$ \\
\hline $\mathrm{I}_{\mathrm{ck}}$ & $546.1 \mathrm{a}$ & $180.0 \mathrm{a}$ & $33.0 \mathrm{a}$ & $217.0 \mathrm{c}$ & $39.7 \mathrm{~d}$ & 149.1 & $27.3 \mathrm{c}$ \\
\hline ANOVA & $* *$ & $* *$ & ** & * & $* *$ & & * \\
\hline
\end{tabular}

ETt: Total evapotranspiration throughout the growing season; PI: percentage of irrigation amount to ETt; PP: percentage of precipitation to ETt; PS: percentage of soil water depletion amount to ETt.

$*$,**Significant at the 0.05 and 0.01 probability levels, respectively.

Distinct letters in the row indicate significant differences according to Tukey's test $(\mathrm{P} \leq 0.05)$. 
indicated that supplemental irrigation based on soil water content could more save irrigation water than conventional irrigation treatment.

The highest soil water depletion (SWD) and percentage of SWD to ETt (PS) occurred in $\mathrm{I}_{0}$. Compared with $\mathrm{I}_{\text {ck }}, \mathrm{I}_{70}$ and $\mathrm{I}_{75}$ increased the SWD by 35.4 and $32.3 \mathrm{~mm}$ in 2008-2009 and by 23.5 and $27.2 \mathrm{~mm}$ in 2009-2010, respectively. Results from our study showed that SWD contributed approximately $60.4 \%$ to $66.2 \%$ of the ETt under rain-fed and $46.0 \%$ to $52.4 \%$ of the ETt under supplemental irrigation conditions, whereas conventional irrigation contributed only $35.0 \%$ to $39.7 \%$ of the ETt during both growing seasons. So supplemental irrigation based on soil water content more promoted the use of soil water than $\mathrm{I}_{\mathrm{ck}}$.

The precipitation amount were 142.8 and $149.1 \mathrm{~mm}$ in 2008-2009 and 2009-2010 growing season, respectively. In both growing seasons, $\mathrm{I}_{0}$ attained the highest percentage of precipitation to ETt $(\mathrm{PP})$. $\mathrm{I}_{70}$ and $\mathrm{I}_{75}$ also obtained higher PP compared with $\mathrm{I}_{\mathrm{ck}}$ by $24.4 \%$ and $10.8 \%$ in $2008-2009$ and $12.8 \%$ and $3.3 \%$ in 2009-2010, respectively. This result showed that a decreasing irrigation amount promoted precipitation use.

Moussa and Abdel-Maksoud (2004) found that the ET value in wheat increased as the amount of irrigation increased. In the present study, a positive linear correlation was observed between irrigation amount and ETt (Figure 2). ETt increased with irrigation amount, and $I_{c k}$ obtained the highest ETt levels of 496.9 and $546.1 \mathrm{~mm}$ in 2008-2009 and 2009-2010, respectively. As irrigation amount decreased, the ETt levels of $\mathrm{I}_{70}$ and $\mathrm{I}_{75}$ decreased by 97.0 and $47.9 \mathrm{~mm}$ in 2008-2009 and 61.7 and $17.9 \mathrm{~mm}$ in 2009-2010 respectively, compared with those of $\mathrm{I}_{\mathrm{ck}} . \mathrm{I}_{0}$ showed the lowest ETt levels of 360.3 and $441.3 \mathrm{~mm}$ in both growing seasons, respectively.

SWD was negatively related to irrigation amount (Figure 3). Xie et al. (2017) also indicated that increasing the irrigation amount results in higher ETt but decreases SWD. Compared with the conventional treatment $\mathrm{I}_{\mathrm{ck}}, \mathrm{I}_{70}$ and $\mathrm{I}_{75}$ promoted the use of soil water and precipitation and saved irrigation water. In contrast, excessive irrigation is detrimental to maximizing SWD and increases water consumption.

\section{ET of individual growth stages}

The sensitivity of growth stages to soil water deficits with respect to grain yield is evident during stem elongation and booting as well as during anthesis and grain filling (del Moral et al., 2003). Supplemental irrigation can be used to satisfy the crop water demand during critical stages, such as the flowering and grain filling stages (Zhang et al., 2013). Tadayon et al. (2012) reported that the rate of grain yield and water productivity in irrigation treatment at the jointing stage is greater than that in other irrigation treatments. We studied the ET values of individual growth stages and their ratio to ETt (Table 5). $\mathrm{I}_{0}$ showed the lowest ET from jointing to anthesis and from anthesis to maturity stages, which may have induced water shortage at critical stages of the growth of wheat and reduced the grain yield. From the jointing to anthesis stage, $\mathrm{I}_{\mathrm{ck}}$

Figure 2. Relationship between irrigation amount (I) and total evapotranspiration (ETt).

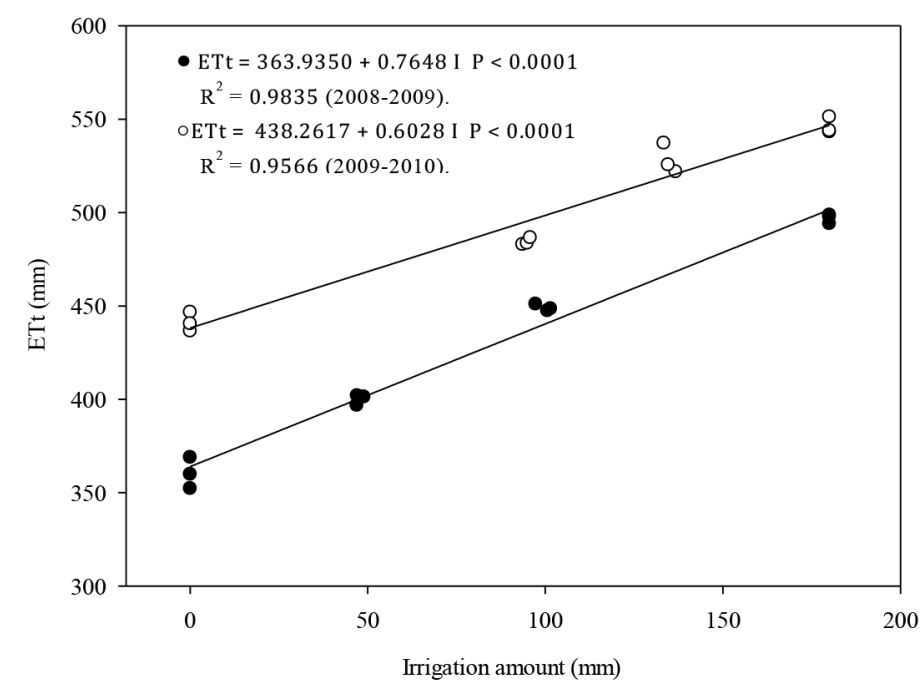


Figure 3. Relationship between irrigation amount (I) and soil water depletion (SWD).

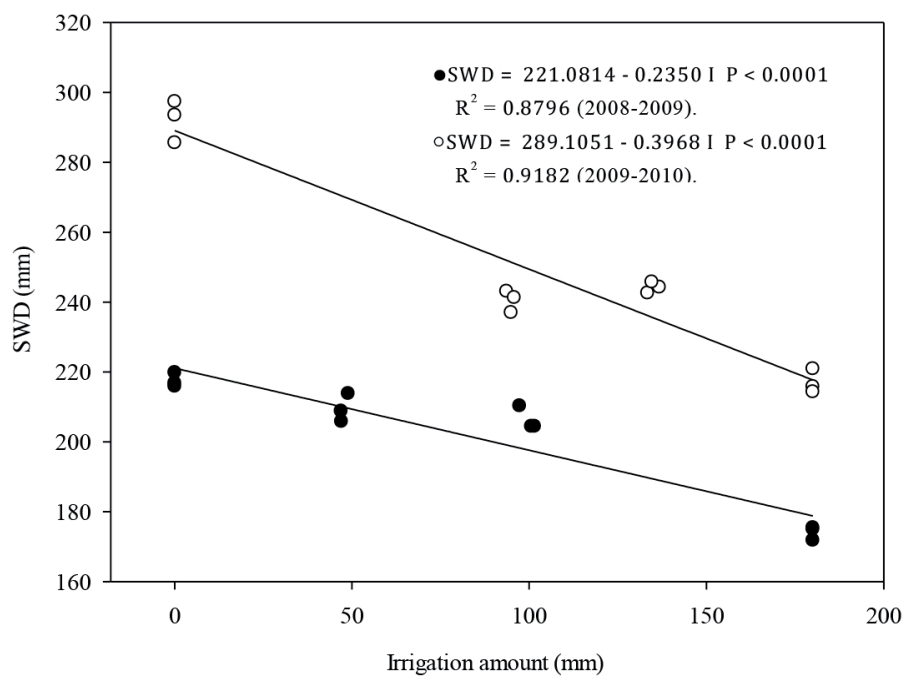

obtained the highest ET of $109.2 \mathrm{~mm}$ in 2008-2009 and $144.1 \mathrm{~mm}$ in 2009-2010, followed by $\mathrm{I}_{75}$, which increased ET by $25.8 \mathrm{~mm}$ in 2008-2009 and $13.7 \mathrm{~mm}$ in 2009-2010 compared with that of $\mathrm{I}_{70}$. However, in anthesis to maturity stage, $\mathrm{I}_{75}$ increased ET relative to $I_{\mathrm{ck}}$ by 11.3 and $25.7 \mathrm{~mm}$, and the ratios to ETt also increased by $16.6 \%$ and $15.7 \%$ in $2008-2009$ and 2009-2010, respectively.

$\mathrm{I}_{75}$ possessed the higher ratio to ETt from the anthesis to maturity stage than other treatments in both growing seasons. This finding suggests that although lower ET occurred in $\mathrm{I}_{75}$ during the entire growing season, it was mainly distributed in the anthesis to maturity stage, which requires the highest water demand of wheat. This finding may explain why $\mathrm{I}_{75}$ generated higher grain yield and WUE.

\section{Dry matter accumulation at different growing stages}

Zhang et al. (2013) reported that the grain yield of winter wheat is significantly related to DM production before heading under rain-fed conditions. DM yields were well correlated to mean production in alfalfa (Bellague et al., 2016). Zeleke and Nendel (2016) stated that irrigated treatments yield significantly higher aboveground DM than rain-fed treatments. The DM accumulation amount (DMAA) at different growing stages is shown in Figure 4. The results indicate that the DMAA increased with the increase in irrigation amount. At the jointing stage, the DMAA of $\mathrm{I}_{\mathrm{ck}}$ was significantly higher

Table 5. Evapotranspiration (ET) of individual growth stages and their ratios to total evapotranspiration (ETt).

\begin{tabular}{|c|c|c|c|c|c|c|}
\hline \multirow[b]{2}{*}{ Treatments } & \multicolumn{3}{|c|}{ ET of individual growth stages (mm) } & \multicolumn{3}{|c|}{ Ratio to ETt (\%) } \\
\hline & $\begin{array}{l}\text { Sowing to } \\
\text { jointing }\end{array}$ & $\begin{array}{l}\text { Jointing to } \\
\text { anthesis }\end{array}$ & $\begin{array}{c}\text { Anthesis to } \\
\text { maturity }\end{array}$ & $\begin{array}{l}\text { Sowing to } \\
\text { jointing }\end{array}$ & $\begin{array}{l}\text { Jointing to } \\
\text { anthesis }\end{array}$ & $\begin{array}{c}\text { Anthesis to } \\
\text { maturity }\end{array}$ \\
\hline \multicolumn{7}{|l|}{ 2008-2009 } \\
\hline $\mathrm{I}_{0}$ & $156.9 \mathrm{~b}$ & $36.3 \mathrm{~d}$ & $167.1 \mathrm{~d}$ & $43.5 \mathrm{a}$ & $10.1 \mathrm{c}$ & $46.4 \mathrm{~b}$ \\
\hline $\mathbf{I}_{70}$ & $156.9 b$ & $39.2 \mathrm{c}$ & $203.8 \mathrm{c}$ & $39.2 b$ & $9.8 \mathrm{~d}$ & $51.0 \mathrm{a}$ \\
\hline $\mathrm{I}_{75}$ & $156.9 b$ & $65.0 \mathrm{~b}$ & $227.1 \mathrm{a}$ & $34.9 \mathrm{c}$ & $14.5 b$ & $50.6 \mathrm{a}$ \\
\hline $\mathrm{I}_{\mathrm{ck}}$ & $171.9 \mathrm{a}$ & $109.2 \mathrm{a}$ & $215.8 b$ & $34.6 \mathrm{c}$ & $22.0 \mathrm{a}$ & $43.4 \mathrm{c}$ \\
\hline ANOVA & $*$ & $* *$ & $* *$ & $* *$ & $* *$ & $* *$ \\
\hline \multicolumn{7}{|l|}{$2009-2010$} \\
\hline $\mathrm{I}_{0}$ & $156.7 b$ & $106.5 d$ & $178.1 \mathrm{c}$ & $35.5 \mathrm{a}$ & $24.1 b$ & $40.4 \mathrm{c}$ \\
\hline $\mathrm{I}_{70}$ & $156.7 b$ & $116.5 \mathrm{c}$ & $211.2 b$ & $32.3 b$ & $24.1 \mathrm{~b}$ & $43.6 b$ \\
\hline $\mathrm{I}_{75}$ & $156.7 b$ & $130.2 b$ & $241.3 \mathrm{a}$ & $29.7 c$ & $24.6 \mathrm{~b}$ & $45.7 \mathrm{a}$ \\
\hline $\mathrm{I}_{\mathrm{ck}}$ & $186.4 \mathrm{a}$ & $144.1 \mathrm{a}$ & $215.6 b$ & $34.1 \mathrm{a}$ & $26.4 \mathrm{a}$ & $39.5 c$ \\
\hline ANOVA & $*$ & $* *$ & $* *$ & $* *$ & $*$ & $* *$ \\
\hline
\end{tabular}

The duration days from sowing to jointing, joint to anthesis and anthesis to maturity are 183, 22 and $38 \mathrm{~d}$ in 2008-2009, and 188, 25 and $36 \mathrm{~d}$ in 2009-2010, respectively.

*,**Significant at the 0.05 and 0.01 probability levels, respectively.

Distinct letters in the row indicate significant differences according to Tukey's test $(\mathrm{P} \leq 0.05)$. 
than that of other treatments. In the anthesis and maturity stages, the DMAA was ranked as $\mathrm{I}_{\mathrm{ck}}>\mathrm{I}_{75}>\mathrm{I}_{70}>\mathrm{I}_{0}$. The DMAA increased by $13.7 \%$ and $6.1 \%$ for $\mathrm{I}_{\mathrm{ck}}$ compared with $\mathrm{I}_{70}$ and $\mathrm{I}_{75}$ in $2008-2009$ and by $12.1 \%$ and $5.7 \%$ compared with $\mathrm{I}_{70}$ and $\mathrm{I}_{75}$ in 2009-2010 at maturity. These results deviate from those of Zhang et al. (2006); in their studies, moderately limited irrigation was an encouraged practice in wheat production, and the irrigation frequency and amount had to be decreased to increase DMAA and improve yield.

\section{Dry matter partitioning in grain and vegetative organ at maturity}

Plant productivity is strongly related to the DM partitioning process, and optimal partitioning of above-ground DM between the vegetative and generative organs is of crucial importance for crop yield (Xu et al., 2018). Varying levels of drought at different growth stages affect the translocation and partitioning of DM in winter wheat and further affect grain yield (Zhang et al., 2012). A certain degree of drought at a certain growth stage could promote assimilation translocation and increase the crop harvest index (Liu et al., 2016); however, in our study, the rain-fed treatment significantly decreased DMAA and ratio in grain compared with those of supplemental irrigation treatments $I_{70}$ and $I_{75}$ at maturity, whereas the partitioning ratio to vegetable organs was significantly increased. Nonsignificant difference was observed in the partitioning ratio in grain and vegetative organs between $\mathrm{I}_{70}$ and $\mathrm{I}_{75}$, but DM partitioning amount in the grain of $\mathrm{I}_{75}$ was significantly higher than that of $\mathrm{I}_{70}$ (Table 6).

Figure 4. Dry matter accumulation amount at different growing stages of wheat.

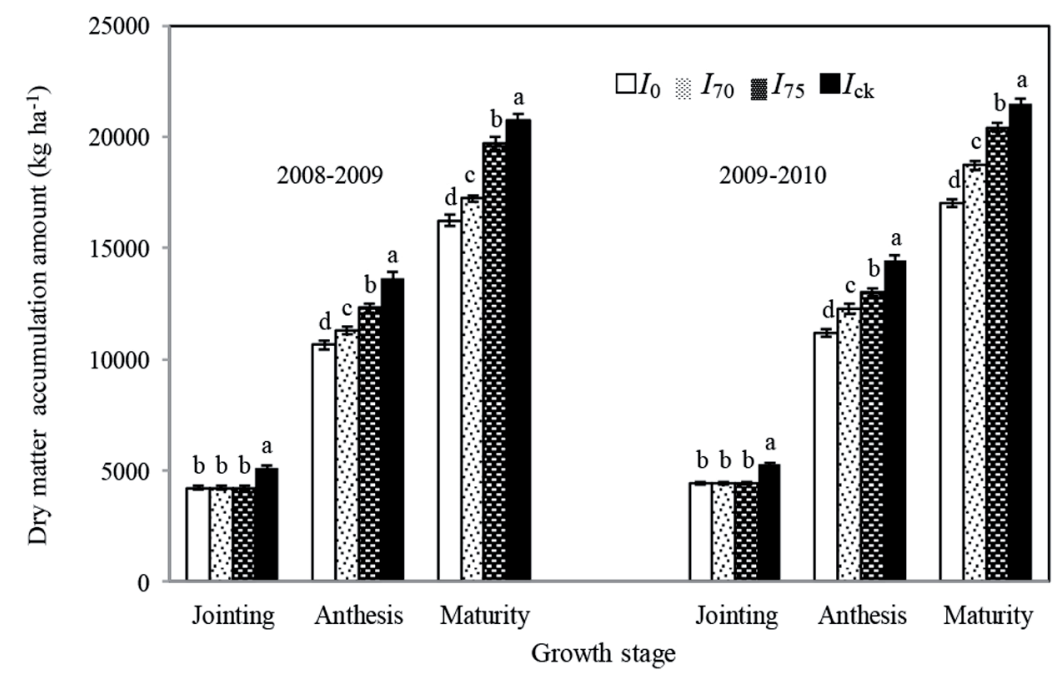

Table 6. Effects of different treatments on DM distribution in different organs at maturity in winter wheat.

\begin{tabular}{ccccc}
\hline & \multicolumn{2}{c}{ Grain } & & \multicolumn{2}{c}{ Vegetative organs } \\
\cline { 2 - 5 } Treatments & Amount & Ratio & Amount & Ratio \\
\hline & $\mathrm{kg} \mathrm{ha}^{-1}$ & $\%$ & $\mathrm{~kg} \mathrm{hm}^{-2}$ & $\%$ \\
$2008-2009$ & $7226.4 \mathrm{c}$ & $44.5 \mathrm{~b}$ & $9012.6 \mathrm{c}$ & $55.5 \mathrm{a}$ \\
$\mathrm{I}_{0}$ & $8186.6 \mathrm{~b}$ & $47.5 \mathrm{a}$ & $9048.4 \mathrm{c}$ & $52.5 \mathrm{~b}$ \\
$\mathrm{I}_{70}$ & $9196.2 \mathrm{a}$ & $46.7 \mathrm{a}$ & $10496.0 \mathrm{~b}$ & $53.3 \mathrm{~b}$ \\
$\mathrm{I}_{75}$ & $9163.3 \mathrm{a}$ & $44.1 \mathrm{~b}$ & $11475.0 \mathrm{a}$ & $55.9 \mathrm{a}$ \\
$\mathrm{I}_{\mathrm{ck}}$ & $* *$ & $*$ & & $*$ \\
ANOVA & & & & \\
$2009-2010$ & $7514.4 \mathrm{c}$ & $44.2 \mathrm{~b}$ & $9486.6 \mathrm{~d}$ & $55.8 \mathrm{a}$ \\
$\mathrm{I}_{0}$ & $8779.7 \mathrm{~b}$ & $46.9 \mathrm{a}$ & $9940.3 \mathrm{c}$ & $53.1 \mathrm{~b}$ \\
$\mathrm{I}_{70}$ & $9435.0 \mathrm{a}$ & $46.2 \mathrm{a}$ & $10987.0 \mathrm{~b}$ & $53.8 \mathrm{~b}$ \\
$\mathrm{I}_{75}$ & $9466.2 \mathrm{a}$ & $44.0 \mathrm{~b}$ & $12048.0 \mathrm{a}$ & $56.0 \mathrm{a}$ \\
$\mathrm{I}_{\mathrm{ck}}$ & $* *$ & $*$ & $* *$ & $*$ \\
ANOVA & & & & \\
\hline
\end{tabular}

$*, * *$ Significant at the 0.05 and 0.01 probability levels, respectively.

Distinct letters in the row indicate significant differences according to Tukey's test $(\mathrm{P} \leq 0.05)$. 
$\mathrm{I}_{\mathrm{ck}}$ obtained a similar DM partitioning amount in grain with $\mathrm{I}_{75}$, but DM partitioning ratio was reduced by $5.6 \%$ in 20082009 and $4.8 \%$ in 2009-2010. Simultaneously, the partitioning ratio in vegetative organs increased by $4.9 \%$ and $4.1 \%$ compared with $\mathrm{I}_{75}$. This result indicated that suitable RSWC treatment $\left(\mathrm{I}_{75}\right)$ promoted the translocation of DM into grains, and lead to the high yield.

\section{Grain yield, WUE, and IWUE}

For different treatments, wheat grain yield varied from 7307.3 to $9085.5 \mathrm{~kg} \mathrm{ha}^{-1}$ in $2008-2009$ and from 7617.6 to 9431.9 $\mathrm{kg} \mathrm{ha}^{-1}$ in 2009-2010 (Table 7). The yield of rain-fed winter wheat was significantly lower than those of the other three treatments. $\mathrm{I}_{75}$ generated the highest yields at $9085.5 \mathrm{~kg} \mathrm{ha}^{-1}$ in 2008-2009 and $9431.9 \mathrm{~kg} \mathrm{ha}^{-1}$ in 2009-2010, and these values were significantly higher than those of $\mathrm{I}_{0}$ and $\mathrm{I}_{70}$ by $24.3 \%$ and $11.4 \%$, respectively, in 2008-2009 and by $23.8 \%$ and $8.3 \%$, respectively, in 2009-2010. The highest grain yield values are higher than those reported in previous studies. For example, irrigating $90 \mathrm{~mm}$ water at jointing and anthesis stages respectively in wheat results in a peak grain yield of 7836 $\mathrm{kg} \mathrm{ha}^{-1}$ in the NCP (Xie et al., 2017). In sprinkler irrigation condition, grain yield varied significantly from 5281 to $2704 \mathrm{~kg}$ ha $^{-1}$ (Rao et al., 2013). Sarwar et al. (2010) found that wheat supplied with five irrigations at crown root, tillering, booting, earing and milking recorded the highest grain yield $\left(5696.8 \mathrm{~kg} \mathrm{ha}^{-1}\right)$. This result proved that supplemental irrigation based on SWC could obtained high yield.

WUE can be enhanced by improving the timing and amount of water application during the growing season (Dabach et al., 2013). Xu et al. (2016) reported that the highest WUE was observed in the limited-irrigation treatment (60 mm water applied at elongation), achieving a relatively high grain yield, whereas sufficient irrigation (a total of $180 \mathrm{~mm}$ water applied) increased grain yield but decreased WUE. In the present study, supplemental irrigation did not increase WUE compared with that of $\mathrm{I}_{0}$. The grain yield of $\mathrm{I}_{75}$ was significantly similar to that of $\mathrm{I}_{\mathrm{ck}}$, while WUE increased by $11.0 \%$ and $3.5 \%$, although the irrigation reduced relative to that of $\mathrm{I}_{\mathrm{ck}}$ by $80.2 \mathrm{~mm}$ in 2008-2009 and $45.1 \mathrm{~mm}$ in 2009-2010 (Table 7).

Supplemental irrigation treatments $I_{70}$ and $I_{75}$ obtained the same IWUE at $17.8 \mathrm{~kg} \mathrm{ha}^{-1} \mathrm{~mm}^{-1}$, which was significantly higher than that of $\mathrm{I}_{\mathrm{ck}}$ by $87.4 \%$ in 2008-2009. In 2009-2010, the highest IWUE of $13.4 \mathrm{~kg} \mathrm{ha}^{-1} \mathrm{~mm}^{-1}$ was obtained by $\mathrm{I}_{75}$; this value was considerably higher than those of $\mathrm{I}_{70}$ and $\mathrm{I}_{\mathrm{ck}}$ by $16.5 \%$ and $34.0 \%$, respectively (Table 7). These results indicate that optimal supplemental irrigation based on soil moisture is necessary to obtain a stable grain yield and WUE. In this study, RSWC was 75\% at jointing and anthesis stages, representing suitable supplemental irrigation in terms of yield and WUE. Thus, our study offers a new standard for developing water-saving irrigation regimes in the NCP.

\section{Relationship between ETt and DM accumulation amount and relationship between ETt and grain yield}

According to Zhang et al. (2008), biomass at heading and maturity and DMAA from heading to maturity (post-heading DM) have a quadratic relationship with ET. In our study, however, a linear correlation was observed between ETt and DMAA. With the increase in ETt, DMAA increased in both growing seasons (Figure 5).

Table 7. Grain yield and irrigation water use efficiency (IWUE).

\begin{tabular}{cccc}
\hline Treatments & Grain yield & WUE & IWUE \\
\hline & $\mathrm{kg} \mathrm{ha}^{-1}$ & & \\
$2008-2009$ & $7307.3 \mathrm{c}$ & $20.3 \mathrm{a}$ & - \\
$\mathrm{I}_{0}$ & $8155.0 \mathrm{~b}$ & $20.4 \mathrm{a}$ & $17.8 \mathrm{a}$ \\
$\mathrm{I}_{70}$ & $9085.5 \mathrm{a}$ & $20.2 \mathrm{a}$ & $17.8 \mathrm{a}$ \\
$\mathrm{I}_{75}$ & $9018.0 \mathrm{a}$ & $18.2 \mathrm{~b}$ & $9.5 \mathrm{~b}$ \\
$\mathrm{I}_{\mathrm{ck}}$ & $* *$ & $*$ & $* *$ \\
$\mathrm{ANOVA}^{-1}$ & & & \\
$2009-2010$ & $7617.6 \mathrm{c}$ & $17.3 \mathrm{a}$ & - \\
$\mathrm{I}_{0}$ & $8710.1 \mathrm{~b}$ & $18.0 \mathrm{a}$ & $11.5 \mathrm{~b}$ \\
$\mathrm{I}_{70}$ & $9431.9 \mathrm{a}$ & $17.9 \mathrm{a}$ & $13.4 \mathrm{a}$ \\
$\mathrm{I}_{75}$ & $9426.3 \mathrm{a}$ & $17.3 \mathrm{a}$ & $10.0 \mathrm{c}$ \\
$\mathrm{I}_{\mathrm{ck}}$ & $* *$ & $\mathrm{~ns}$ & $* *$ \\
ANOVA & & & \\
\hline
\end{tabular}

WUE: Water use efficiency.

*,**Significant at the 0.05 and 0.01 probability levels, respectively. ns: Nonsignificant. Distinct letters in the row indicate significant differences according to Tukey's test $(\mathrm{P} \leq 0.05)$. 
A linear relationship between wheat grain yield and ETt was reported by Zhang et al. (2013). In contrast to their results, a quadratic relationship between ETt and grain yield, with an $\mathrm{R}^{2}$ of 0.9508 for 2008-2009 and 0.9807 for 2009-2010, was observed in our study (Figure 6). Based on the regression functions, grain yield increased within a certain scope of ETt. However, the grain yield peaked at the ETt value of $482.6 \mathrm{~mm}$ in 2008-2009 and $555.7 \mathrm{~mm}$ in 2009-2010, and grain yield started to decrease when the ETt levels exceeded the critical value.

These results indicate that higher ETt can produce more DM, whereas grain yield cannot increase correspondingly because of the limiting of DM partitioning in grains at maturity.

\section{CONCLUSION}

Summer is rainy in the North China Plain (NCP), and soil water can replenish winter wheat to a certain extent. In this study, a new irrigation method was adopted in which the relative soil water content (RSWC) of 0 to $140 \mathrm{~cm}$ soil layer was tested before irrigation at the jointing and anthesis stages and the amount of supplemental irrigation was calculated using a formula. The results indicate that the irrigation amount of supplemental irrigation based on SWC significantly decreases compared with conventional irrigation but promotes the use of soil water and precipitation and increases the ratio to total evapotranspiration (ETt) in the anthesis to maturity stage.

Figure 5. Relationship between total evapotranspiration (ETt) and DM accumulation amount (DMAA).

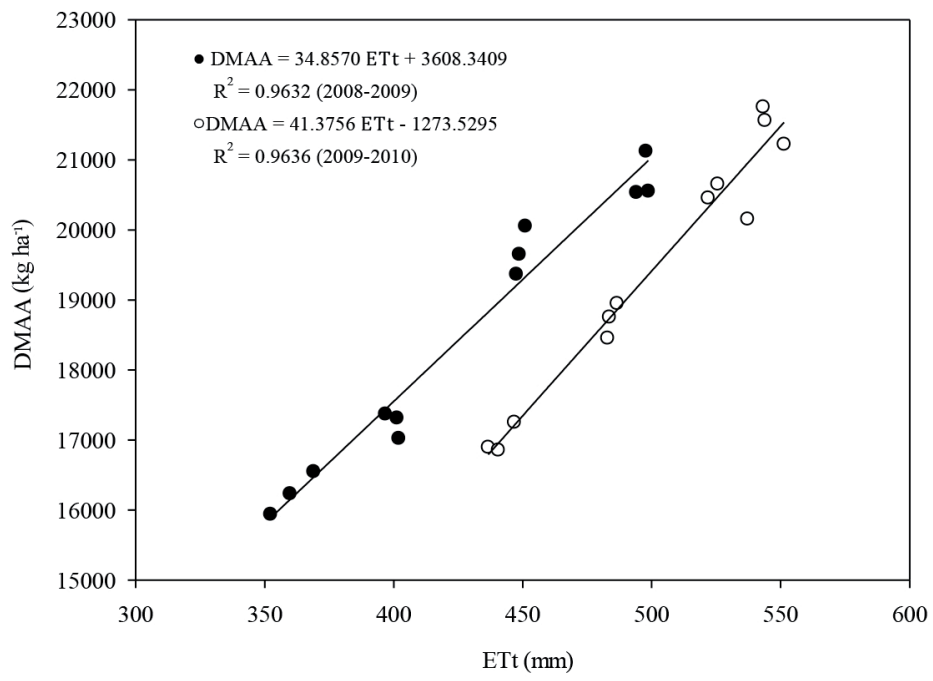

Figure 6. Relationship between total evapotranspiration (ETt) and grain yield (GY).

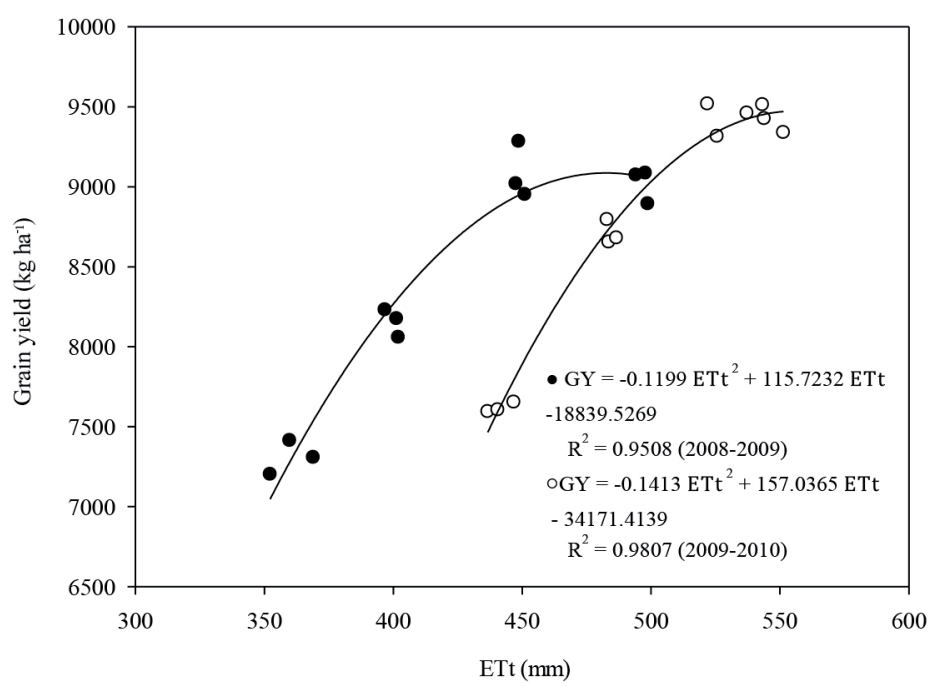


This study has also shown that supplemental irrigation based on SWC positively influences the wheat biomass production compared with conditions without irrigation. Although the DM accumulation amount (DMAA) of supplemental irrigation treatment $\mathrm{I}_{75}$ (the controlled average target relative SWC in the 0 to $140 \mathrm{~cm}$ soil layer at jointing and anthesis stages reached $75 \%$ ) decreased compared with conventional irrigation treatment, the value increased the DM partitioning ratio in grain, thereby increasing the DMAA in grain at maturity.

Under $\mathrm{I}_{75}$ irrigation treatment, higher water use eficiency (WUE) and irrigation WUE (IWUE) could be achieved with no penalties in yield. Optimum targeting irrigation based on SWC can make the wheat production maximized and is fundamental for water saving and increasing WUE in NCP of China.

\section{ACKNOWLEDGEMENTS}

This research was funded by the National Natural Science Foundation of China (31771717, 31101115), by the Natural Science Foundation of Shandong Province (ZR2016CM34), and by the Project of China Agriculture Research System (CARS-3-1-19).

\section{REFERENCES}

Abdelkhalek, A.A., Darwesh, R.K., and Mona, A.M.E. 2015. Response of some wheat varieties to irrigation and nitrogen fertilization using ammonia gas in North Nile Delta region. Annals of Agricultural Science 60:245-256.

Ali, M.H., Hoque, M.R., Hassan,A.A., and Khair, A. 2007. Effects of deficit irrigation on yield, water productivity, and economic returns of wheat. Agricultural Water Management 92:151-161.

Bellague, D., M'Hammedi-Bouzina, M., and Abdelguerfi, A. 2016. Measuring the performance of perennial alfalfa with drought tolerance indices. Chilean Journal of Agricultural Research: 76:273-284.

Cai, T., Xu, H., Peng, D., Yin, Y., Yang, W., Ni, Y., et al. 2014. Exogenous hormonal application improves grain yield of wheat by optimizing tiller productivity. Field Crops Research 155:172-183.

Cui, Y.K., Tian, Z.W., Zhang, X., Muhammad, A., Han, H.M., Jiang, D., et al. 2015. Effect of water deficit during vegetative growth periods on post-anthesis photosynthetic capacity and grain yield in winter wheat (Triticum aestivum L.) Acta Physiologiae Plantarum 37:196.

Dabach, S., N. Lazarovitch, Simunek, J., and Shani, U. 2013. Numerical investigation of irrigation scheduling based on soil water status. Irrigation Science 31:27-36.

del Moral, L.F.G., Rhrarrabti, Y., Villegas, D., and Royo, C. 2003. Evaluation of grain yield and its components in durum wheat under Mediterranean conditions: An ontogenic approach. Agronomy Journal 95:266-274.

Fang, Q., Zhang, X.Y., Shao, L.V., Chen, S.Y., and Sun, H.Y. 2018. Assessing the performance of different irrigation systems on winter wheat under limited water supply. Agricultural Water Management 196:133-143.

Hayriye, I., Mahmut, C., Ebru, K., Wolfgang, A.F., Burak, T., Yunus, B., et al. 2015. Irrigation-induced nitrate losses assessed in a Mediterranean irrigation district. Agricultural Water Management 148:223-231.

Li, Q.Q., Liu, M.Y., Zhang, J.W., Dong, B.D., and Bai, Q. 2009. Biomass accumulation and radiation use efficiency of winter wheat under deficit irrigation regimes. Plant Soil and Environment 55:85-91.

Li, P., Wu, P.T., and Chen, J.L. 2012a. Evaluation of flag leaf chlorophyll content index in 30 spring wheat genotypes under three irrigation regimes. Australian Journal of Crop Science 6:1123-1130.

Li, Q.Q., Zhou, X.B., Chen, Y.H., and Yu, S.L. 2012b. Water consumption characteristics of winter wheat grown using different planting patterns and deficit irrigation regime. Agricultural Water Management 105:8-12.

Liu, E.K., Mei, X.R., Yan, C.R., Gong, D.Z., and Zhang, Y.Q. 2016. Effects of water stress on photosynthetic characteristics, dry matter translocation and WUE in two winter wheat genotypes. Agricultural Water Management 167:75-85.

Lv, L.H., Wang, H.J., Jia, X.L., and Wang, Z.M. 2011. Analysis on water requirement and water-saving amount of wheat and corn in typical regions of the North China Plain. Frontiers of Agriculture in China 5:556-562.

Man, J.G., Yu, Z.W., Zhang, Y.L., Shi, Y., and Wang, L.Q. 2016. Water and nitrogen use of winter wheat under different supplemental irrigation regimes. Crop Science 56:1-13.

Moussa, A.M., and Abdel-Maksoud, H.H. 2004. Effect of soil moisture regime on yield and its components and water use efficiency for some wheat cultivars. Annals Agricultural Sciences 49:515-530.

Peake, A.S., Carberry, P.S., Raine, S.R., Gett, V., and Smith, R.J. 2016. An alternative approach to whole-farm deficit irrigation analysis: Evaluating the risk-efficiency of wheat irrigation strategies in sub-tropical Australia. Agricultural Water Management 169:61-76.

Rao, S.S., Regar, P.L., Tanwar, S.P.S., and Singh, Y.V. 2013. Wheat yield response to line source sprinkler irrigation and soil management practices on medium-textured shallow soils of arid environment. Irrigation Science 31:1185-1197. 
Sarwar, N., Maqsood, M., Mubeen, K., Shehzad, M., Bhullar, M.S., Qamar, R., et al. 2010. Effect of different levels of irrigation on yield and yield components of cultivars. Pakistan Journal of Agricultural Sciences 47:371-374.

Schillinger, W.F., Schofstoll, S.E., and Alldredge, J.R. 2008. Available water and wheat grain yield relations in a Mediterranean climate. Field Crops Research 109:45-49.

Shi, W.J., Tao F.L., and Liu J.Y. 2013. Changes in quantity and quality of cropland and the implications for grain production in the Huang-Huai-Hai Plain of China. Food Security 5:69-82.

Stolpe, N., and Undurraga, P. 2016. Long term climatic trends in Chile and effects on soil moisture and temperature regimes. Chilean Journal of Agricultural Research 76:487-496.

Suat, I., Koffi, D., and Daran, R.R. 2016. Effect of full and limited irrigation amount and frequency on subsurface drip-irrigated maize evapotranspiration, yield, water use efficiency and yield response factors. Irrigation Science 34:271-286.

Tadayon, M.R., Ebrahimi, R., and Tadayyon, A. 2012. Increased water productivity of wheat under supplemental irrigation and nitrogen application in a semi-arid region. Journal of Agricultural Science and Technology 14:995-1003.

Tari, A.F. 2016. The effects of different deficit irrigation strategies on yield, quality, and water-use efficiencies of wheat under semi-arid conditions. Agricultural Water Management 167:1-10.

Wang, X.P., Huang, G.H., Yang, J.S., Huang, Q.Z., Liu, H.J., and Yu, L.P. 2015. An assessment of irrigation practices: Sprinkler irrigation of winter wheat in the North China Plain. Agricultural Water Management 159:197-208.

Wu, Y.L., Guo, Q.F., Luo, Y., Tian, F.X., and Wang, W. 2014. Differences in physiological characteristics between two wheat cultivars exposed to field water deficit conditions. Russian Journal of Plant Physiology 61:451-459.

Xie, Y.X., Zhang, H., Zhu, Y.J., Li, Z., Yang, J.H., Cha, F.N., et al. 2017. Grain yield and water use of winter wheat as affected by water and sulfur supply in the North China Plain. Journal of Integrative Agriculture 16:614-625.

Xu, C.L., Tao, H.B., Tian, B.J., Gao, Y.B., Ren, J.H., and Wang, P. 2016. Limited-irrigation improves water use efficiency and soil reservoir capacity through regulating root and canopy growth of winter wheat. Field Crops Research 196:268-275.

Xu, J.K., Yu,Z.W., Shi, Y., Guo, P.W., and Wang, Y.Q.2017.Effect of different supplemental irrigation strategies on photosynthetic characteristics and water use efficiency of wheat. Chilean Journal of Agricultural Research 77:346-354.

Xu, X.X., Zhang, M., Li, J.P., Liu, Z.Q, Zhao, Z.G., Zhang, Y.H, et al. 2018. Improving water use efficiency and grain yield of winter wheat by optimizing irrigations in the North China Plain. Field Crops Research 221:219-227.

Zadoks, J.C., Chang, T.T., and Konzak, C.F. 1974. A decimal code for the growth stages of cereals. Weed Research 14:415-421.

Zeleke, K.T., and Nendel, C. 2016. Analysis of options for increasing wheat (Triticum aestivum L.) yield in south-eastern Australia: The role of irrigation, cultivar choice and time of sowing. Agricultural Water Management 166:139-148.

Zhang, X.Y., Chen, S.Y., Sun, H.Y., Pei, D., and Wang, Y.M. 2008. Dry matter, harvest index, grain yield and water use efficiency as affected by water supply in winter wheat. Irrigation Science 27:1-10.

Zhang, M.M., Dong, B.D., Qiao, Y.Z., Shi, C.H., Yang, H., Wang, Y.K., et al. 2018. Yield and water use responses of winter wheat to irrigation and nitrogen application in the North China Plain. Journal of Integrative Agriculture 17:1194-1206.

Zhang, B.C., Li, F.M., Huang, G.B., Cheng, Z.Y., and Zhang, Y.H. 2006. Yield performance of spring wheat improved by regulated deficit irrigation in an arid area. Agricultural Water Management 79:28-42.

Zhang, X.Y., Qin, W.L., Chen, S.Y., Shao, L.W., and Sun, H.Y. 2017. Responses of yield and WUE of winter wheat to water stress during the past three decades-a case study in the North China Plain. Agricultural Water Management 179:47-54.

Zhang, H., Turner, N.C., and Poole M.L. 2012. Increasing the harvest index of wheat in the high rainfall zones of southern Australia. Field Crop Research 129:111-123.

Zhang, X., Wang, Y., Sun, H., Chen, S., and Shao, L. 2013. Optimizing the yield of winter wheat by regulating water consumption during vegetative and reproductive stages under limited water supply. Irrigation Science 31:1103-1112. 